\title{
Translating Climate Change Impacts at the Community Level
}

\author{
FRANK DUERDEN ${ }^{1}$
}

\author{
(Received 12 March 2003; accepted in revised form 19 January 2004)
}

\begin{abstract}
It is well recognized that climate change will have considerable impact on the physical landscapes of northern Canada. How these impacts will be transmitted to the level of human activity is not clear, but it needs to be understood by governments and other decision makers to help them identify and implement appropriate approaches to ameliorate the effects of climate change. Translating physical changes into human impacts is not a simple task; communities are not passive players that will respond to changes in the physical environment in easily predictable ways. While many prognoses about change are made on a large scale, human activity is highly localized, and impacts and responses will be conditioned by local geography and a range of endogenous factors, including demographic trends, economic complexity, and experience with "change" in a broad sense. More and more studies are yielding important information about community-level experience, both past and current, with environmental shifts in the North, but research effort by social scientists falls short of what is required to reduce the level of uncertainty, and it compares unfavourably with the physical sciences' dedication to the climate change problem. A pan-northern research effort, building on a long legacy of social science research in the North, would go some way towards translating the promise of change into probable community impacts.
\end{abstract}

Key words: climate change, community impact, land use, traditional knowledge, response, uncertainty

RÉSUMÉ. Il est bien connu que le changement climatique va avoir un impact considérable sur le paysage physique du nord du Canada. La façon dont ces retombées vont se transmettre au niveau de l'activité humaine n'est pas claire, mais les gouvernements et d'autres décideurs doivent la comprendre afin de pouvoir cerner et mettre sur pied des approches visant à amortir ces retombées. Traduire des changements physiques en répercussions humaines relève plus que d'une simple tâche; les communautés ne sont pas des intervenants passifs qui vont réagir au changement de leur milieu physique de façon nettement prévisible. Si bien des pronostics au sujet du changement sont établis sur une grande échelle, l'activité humaine, elle, est très localisée, et les impacts et réactions seront conditionnés par la géographie locale et par une gamme de facteurs endogènes, y compris les tendances démographiques, la complexité économique et l'expérience du «changement» au sens large. De plus en plus d'études fournissent de l'information importante sur l'expérience - passée comme actuelle - qui se vit au niveau de la communauté en rapport avec les changements environnementaux dans le Nord. Les travaux de recherche des spécialistes en sciences sociales ne sont toutefois pas à la hauteur pour diminuer le niveau d'incertitude, et ils se comparent mal à la détermination des sciences physiques de s'attaquer au problème du changement climatique. Des travaux à l'échelle du Nord, qui s'appuieraient sur une longue tradition de recherche en sciences sociales dans le Nord, aideraient dans une certaine mesure à traduire la promesse de changements en retombées probables au niveau des communautés.

Mots clés: changement climatique, retombées au niveau des communautés, utilisation du sol, savoir traditionnel, réponse, incertitude

Traduit pour la revue Arctic par Nésida Loyer.

\section{INTRODUCTION}

Climate change research in northern Canada serves a number of purposes. Changes in the circumpolar environment are of global significance, while elements of the Arctic landscape provide an excellent natural laboratory for investigation of past and future trends (Hughen et al., 1998). Beyond the satisfaction of scientific curiosity, the local importance of climate change research lies in identifying impacts on human populations and formulating appropriate responses (Lewis and Wood, 1995; Cutter, 1996; Watson et al., 1997; Adger and Kelly, 1999; Handmer et al., 1999; Kelly and Adger, 2000). While physical evidence of climate change at high latitudes is now overwhelming
(Comiso, 2003), "uncertainty" best characterizes our current level of knowledge about its impact on human activity. The uncertainty is magnified by the considerable difference between the large scale at which we gather physical data and generate scenarios and the distinct local geographies of the widely dispersed communities where change will be experienced. Research effort focused on community perceptions of climate change is increasing (Berkes, 1999; Cruikshank, 2001; Nuttall, 2001; Reidlinger and Berkes, 2001; Fox, 2002; Krupnik and Jolly, 2002), but climate change scenarios often depict Northerners and northern communities as passive actors. Relatively little attention has been given to the way in which a complex synergy of factors-such as local conditions, population

${ }^{1}$ Department of Geography, Ryerson University, 350 Victoria Street, Toronto, Ontario M5B 2K3, Canada; fduerden@ arts.ryerson.ca

(C) The Arctic Institute of North America 
attitudes, cultural history, or economic relationshipswill condition their responses to change. Understanding how climate change may affect the well-being of communities by damaging infrastructure or economy, as well as the likely response of a community to such stresses, is important to governments at all levels. Communities will need to assess the magnitude of possible changes and anticipate their local effects, and central governments will face the difficult problem of allocating limited resources over a wide range of locations to help mitigate the impact of climate change.

Identification of the nature of climate change is the legitimate prerogative of physical scientists, while social sciences are arguably best equipped to investigate how physical change will be translated through the filter of human activity and interaction at the community level. Nuttall (2001:33) observed that "socio-economic scenarios are vital for the Indigenous people of the Arctic and yet are poorly developed and inadequate." This statement reflects the reality that physical scientists, though they concede their prognoses of climate trends are inexact and fuel a sense of uncertainty, are somewhat ahead of the social scientists who are investigating the human consequences of climate change in the Arctic. The present study examines critically the current role of social scientists in assessing impacts of climate change on communities in northern Canada. It makes a case for a broad, systematic approach to assessing community vulnerability, one that is cognizant of geographic scale and community history as major determinants of response. Recognition that climate change is an emerging fact of life in the North, resulting in drastic modifications to permafrost regimes, sea ice conditions, snow cover, vegetation, and wildlife habitats, is well documented (Cohen, 1997; Maxwell, 1997; Taylor and Taylor, 1997; IASC, 1999). The most commonly articulated concerns about impacts relate to the structural integrity of buildings, modifications of the community economic base, impacts on traditional food harvests and transportation, and shifts in industrialization, flooding, forest fires, and landslides (NCE, 2000). While the volume of literature addressing impacts has increased markedly over recent years, there is still a deficiency of relevant practical material. Of the 106 reports in the Northern Climate ExChange (NCE) database that dealt with human impacts, half were more than six years old (and therefore of questionable currency), and only 19 perhaps had some relevance to the community scale (Duerden, 2001). Many reports tend to reflect physical prognoses about northern climate in that they address change at the large scale. For example, the frameworks presented by the International Arctic Science Committee (IASC, 1999) for evaluating impacts in the Arctic are centered on infrastructure, and the analysis suggests that significance of impacts should be evaluated at the regional or even the national scale.

Until recently, studies addressing specific implications of climate change have also tended to be at a relatively large scale. The federal government has produced broad studies of possible changes in the Yukon (Taylor and Taylor, 1997) and the Arctic (Maxwell, 1997). More focused studies include the Canadian Arctic Resources Committee's review of possible stresses in Hudson Bay (McDonald et al., 1997) and the Mackenzie Basin Impact Study (Cohen, 1997), which recognized the complex framework of integrated regional systems within which impacts must be evaluated (Lonegran et al., 1993; Huang et al., 1998). A plethora of sectoral studies have examined impacts of change on specific aspects of life in the Arctic, also at the large scale. They identify impacts of warming as various as increased incidence of "natural hazards," communication disruption, and stresses on traditional harvesting (Aharonian, 1994; Fast and Berkes, 1998), changes in forest resources (Rothman and Herbert, 1997), expansion of northern agriculture (Mills, 1994), and increased oil and natural gas development resulting from cheaper, more reliable navigation in Arctic waters (McGillivary et al., 1993). Together these reports have acted importantly to increase awareness of climate change and its possible impacts, indicating both the direction in which things are moving and the clear need to develop responses. However, they are generally inappropriate for application at the highly local scale of the 96 diverse communities that contain northern Canada's population.

\section{COMMUNITIES AND CLIMATE CHANGE}

In climate change scenarios, human activity sits at the end of a chain that begins with General Circulation Models (GCMs). Modeling has improved markedly over the years, but still needs refinement (IPCC, 2001), and uncertainty is compounded at every step as the geographically broad climate change scenarios produced by GCMs are translated into regional and local biophysical impacts, and finally into impacts on human activity at the community level (Berkes, 2002). Changing environments will be experienced differently in each of the communities dispersed across Canada's highly diverse northern landscape. It is obvious that environmental changes in Old Crow at the edge of the boreal zone in the western Arctic will be different from those affecting maritime Iqaluit on the northern Shield in the east, and Arctic Red River's experience will be different from that in Baker Lake or Sachs Harbour. But it is further postulated here that even communities within the same eco-zone may experience different effects from identical climate-related events because of marked local variations in site, situation, culture, and economy. Recent work suggests that change will first become manifest in variability, unpredictability, and an increased incidence of extreme events (Fox, 2000, 2002; Huntington, 2000; Snow and Carpenter, 2001; Jolly et al., 2002; Thorpe et al., 2002). For individuals and households, unpredictability and extreme events will be reflected in their inability to make decisions with anything like the same certainty or the same range of probable error 
as in the past. Later, change will be more forcibly experienced in long-term modifications to landscapes and shifts in wildlife habitats.

\section{DETERMINANTS OF COMMUNITY RESPONSES}

Even if we knew with a high degree of certainty how the local physical environmental context might change, it would be wrong to view the community as a "passive player" whose reaction is predictable. Community response will largely be determined by existing conditions: by endogenous factors that vary considerably from location to location, reflecting variations in culture, economy, social history, and land-use practices. Two broad approaches to assessment of probable climate change impacts can be identified. The inductive approach uses information and research results generated for other purposes, such as demographic analysis and economic base studies, as the basis for informed speculation about possible climate change impacts. The empirical approach draws on a population's observations of environmental shifts and changes in their way of life. Here traditional knowledge and the direct experiences of affected populations lie at the core of the research effort. Traditional knowledge is admirably suited to local-scale analysis, as it incorporates a long, experience-based history and describes current and past geographies and landscapes in considerable detail. The manner in which it speaks of activities that have a strong climatic context-including how to navigate, how to forecast the weather, how to read snow and ice conditions, and how ecosystems and wildlife behave-makes it especially relevant.

The demography and economy of the community and the population's view of the reality or expectation of change are the filters that condition the way physical changes in environment will be experienced at the local level. Examination of these aspects of community life illustrate the difficulty of translating expected environmental changes directly into local impacts and make obvious the need to develop a systematic understanding of community-level conditions.

\section{Population Characteristics}

Demographic composition of northern communities varies greatly. Most settlements have hybrid populations of original peoples and migrants from the south. A lesser number contain almost exclusively indigenous populations, and others consist largely of southern migrants. Population composition tends to be reflected in variation in turnover rates, which in turn are an important determinant of attitudes towards change. Populations in the North turn over very quickly. In the period 1995-2000, the Northwest Territories' turnover was $37 \%$ of its nominally stable population of ca. 40000 (Government of Northwest Territories, 2003). For the Yukon, the figure was even higher-
$66 \%$ of a nominally steady-state population of ca. 30000 (Government of Yukon, 2002). These figures are crude, since some communities may have far more multiple entries and exits of population than others, but they are a fair indicator of attachment to place. Some places (mining settlements) display rapid short-term turnover rates, while largely Native communities tend to have older and more stable populations, and these contrasts can produce considerable differences in community memory of past events. Communities with an economy tied to mining, for example, tend to have relatively short life spans and highly transient populations, populations that can be broadly characterized as perpetually young. Populations flow through such communities very rapidly: children rarely become adults, and very few people become old. In such communities, there is little sense of change or longer-term cycles of events. Newcomers may view as the norm events that others perceive to be related to global warming, because the current world is all they know. Furthermore, change may not really matter to people of such communities because transient populations do not have to live with the long-term consequences.

Conversely, communities that retain strong links to the land contain older people, mature families, and long memories. Historically, dependence on the physical environment of a locale for livelihood made both contemporary and intergenerational transmission of detailed traditional environmental knowledge (TEK) central to sustained wellbeing. TEK is increasingly used to identify environmental change in the North by corroborating scientific information, adding new information about environmental changes, and providing geographical information at the appropriate scale (Duerden and Kuhn, 1998; Riedlinger and Berkes, 2001). Ideally, perhaps its greatest value lies in keeping alive the important stories of past places, practices and events, thus facilitating the intergenerational flow of information that depicts dynamic and highly localized environmental histories. The reoccurring message, that the North is a place of stress and change, is significant as sedentary living and technological fixes increasingly lessen a population's connection to the immediate physical environment.

While differences in population stability provide insights into different ways of perceiving climate change, a further factor influencing community adaptation to change is the pace or amplitude of change in comparison to the human life span. A change in state over a century or more would span several generations. Thus, while rapid as a physical process, it would appear from the human perspective to be relatively slow and of little significance. In this case, not only would populations of settlements with high population turnover rates be barely affected, but even longestablished populations would perhaps not view the changes as alarmingly significant. Contemporary evidence suggests that this perspective is overly optimistic. First, it appears that the process of change will be characterized by increased variability of weather and by significant climatic events (IASC, 1999). Secondly, anecdotal evidence 
from Hudson Bay suggests that the speed of events may outstrip the people's ability to adapt: "In the past, when [the elders] said, "it's going to be like this tomorrow," it was. But our weather and environment are changing, so our knowledge isn't true all the time now" (McDonald et al., 1997:28). Similar observations have been made regarding Banks Island (Snow and Carpenter, 2001).

\section{Community Economies}

At first glance, the economies of northern communities seem quite simple, a reflection of their small size and dearth of economic opportunities. The economies of longerestablished settlements are generally a hybrid of the traditional land-based sector and a formal wage economy, while mining communities have a preponderance of industrial employment and a small service base. This notion of simplicity is reflected in the tendency to view the employment impacts of climate change sector by sector, with various studies postulating impacts on food harvesting, trapping, mining, tourism, power generation, highway maintenance, and winter road construction (Lonegran et al., 1993; Mills, 1994; Fast and Berkes, 1998). The general prognosis is that some sectors, notably harvesting and tourism, may be stressed, while others, such as energy and agriculture, will benefit from warming.

The small size of communities belies the fact that economic and social structures are highly complex with (typically) considerable interaction and interdependence between traditional harvesting, the wage sector, and monies flowing into a community in the form of various transfer payments (welfare, pensions, child allowances, etc). Changes in one sector will have implications for others, and the matrix of interdependence suggests that a holistic perspective on these economies is required to really understand community impacts. For example, "single sector" analysis of the impact of warming on country food harvests indicates that species shifts or decline could lead to a greater reliance on store-bought food (Wein and Wein, 1995). Effects, it is argued, will vary from region to region. Changes in vegetation as the tree line advances will enhance food supply for wildlife species such as deer, moose, and bear, while decreased runoff may deplete biologically rich areas in the northern deltas. In the Arctic Ocean, changes in sea-ice conditions and unpredictable weather could lead to reduced marine harvests. If this observation is placed in the holistic context of a community economy, a more complex picture emerges. Data from a classic study of the economic base of Sanikiluaq in Hudson Bay illustrate this point. Quigley and McBride (1987) mapped out the structure of the community microeconomy in detail, identifying transactions between the wage and non-wage sectors, the former consisting of services and government and the latter of hunting, trapping, fishing, and the taking of seals. Using imputed replacement values, the annual per capita value of country food and the taking of furs was estimated to total some
$56 \%$ of community income. However, given that most salaried employment (teaching, government administration) lay in the hands of non-Natives, the total imputed value actually constituted $70 \%$ of Native household income. Because of its direct links to the ecosystem, traditional harvesting is most at risk from climate change, and if harvests were adversely affected, the only alternative would be store-bought food, which is expensive in northern communities. The outcome would be that the portion of society with the lowest cash income would have to spend more money on foodstuffs to compensate for the loss. From the standpoint of physical health, a shift to increased dependence on store-bought food could be a mixed blessing. It might mitigate the adverse impacts that may arise as warming increases contaminants in the country food chain, but could also give rise to new medical problems as processed foods increasingly replace traditional diet.

The scenario described here may be overly negative. Recent events, such as settlement of comprehensive land claims across northern Canada and the emergence of Nunavut, will result in devolution of government jobs and a broader range of wage employment opportunities. This may go some way towards offsetting stresses created in those areas where environmental change would lead to a decrease in food harvests. Additional employment opportunities may also arise if sustained demand and changing ocean conditions make hydrocarbon extraction and transport cheaper. The extent to which new employment opportunities would offset losses in the traditional sector would depend on cultural acceptance of new activities and the rate at which emerging activities could absorb local labour. There is evidence that the shift from land-based economies to the tertiary and industrial sectors has accelerated in recent years, even without the impetus of climate change. Usher (2002) cites increases in wage labour as partially responsible for changes in the location of, and participation in, food harvests in the western Arctic.

Very little is known about the way in which community businesses may react to climate change, but it is not unreasonable to speculate that the life cycle of enterprises and the past behaviour of northern economies will influence the significance of climate impacts on entrepreneurial activity. Much of the North has long been an environment of uncertainty for the business sector. External market conditions have historically dictated boombust cycles and the subsequent growth and collapse of entrepreneurial activity, with much activity having a short life span. The physical context in which businesses operate will assume increased importance as climate changes. Those enterprises most dependent on local conditions such as transport, tourism, agriculture, and processing of wildlife products - will be most directly affected. Given the historical instability of the North's formal economy, adjustment to climate change might not be excessively disruptive. Recently established businesses may view the changing world as the norm; others might cease to exist, 
perhaps to be replaced by businesses more attuned to the emerging environment.

\section{Communities and Change}

To the popular imagination, the notion of climate change in a land that is popularly represented as a cold and undifferentiated place in which nothing much happens has a certain cataclysmic appeal. Often lost in the babble about stress, adaptation, and the need to be prepared for the unknown is appreciation of the long-term environmental history and adaptability of northern populations. For much of the year, Arctic communities lie on the threshold of ice and water, of freezing and melting, in environments where minor temperature fluctuations bring about highly significant changes of state. Changes that may be regarded as minor elsewhere assume larger importance there because of their amplification in the narrow ecosystem. Northern landscapes are subject to violent climate-induced events annually. As long winters explode into spring, river volumes increase dramatically; soils become viscous as ice melts, resulting in floods and landslides. In the summer, storms bring forest fires to the boreal zone. While these events are cyclical in nature (and therefore expected), they nevertheless are the source of considerable environmental stress. Current research in the Yukon is examining the incidence of climatically generated hazard events, particularly adverse winter conditions, flooding, and forest fires, in the period 1989-2000. It has revealed some 264 events, 127 of which were of significant magnitude to require a formal response in the form of emergency measures or ameliorative action (K. Gad, pers. comm. 2002). First Nation narratives speak of cataclysmic changes in local environments (Cruikshank, 2001), and the longer-term historical record tells of shifts and swings in wildlife populations possibly related to climatic perturbations. The paleoclimatic record paints a picture of considerable variability through the Holocene, with a maximum variation in mean temperature of $6^{\circ} \mathrm{C}$ (Hughen et al., 1998). It is debatable to what extent exposure to the stresses that northern communities periodically experience will condition their responses to climate change. Smit and Pilifosova (2002) observe that communities can generally deal with some deviation from average conditions, but changes in the incidence and nature of extreme events will challenge their ability to cope.

The North's Indigenous populations are certainly not neophytes in dealing with climate-generated stress. To longer-established Northerners, the message received from the outside - that climate change is coming and they must be prepared for it - may seem particularly ironic, especially when seen in the context of a broadly changing world. Virtually within generational recall, populations have become sedentary, traditional land-based activities have declined, industrialization and consumerism have been introduced, the ethno-demographic makeup of society has shifted, and food sources have been tainted by global contaminants. Fox (2002:45) noted the tendency of eastern Arctic Inuit, when asked about climate change, to talk about a wide range of other stressors. "While climate change is clearly a concern for the Inuit," she observed, "it is important to recognize that there are other, often more pressing problems, facing communities." Her statement reflects the reality that, when weighed against the litany of contemporary problems facing communities, consideration of climate change implications may be a low priority.

Changing environments and their impact on local populations are the object of a large and rapidly growing body of empirical studies, almost all of which draw on traditional knowledge as source information (e.g., McDonald et al., 1997; Williamson, 1997; Huntington, 2000; Kendrick, 2000; Noongwook, 2000). Traditional knowledge-based studies vary somewhat in methodology, spatial scale, and subject matter. The range of approaches and ways in which they can inform the debate about local impacts is exemplified in Cruikshank's (2001) narrative of historic glacial surges in Alaska, the community descriptions of contemporary environmental changes in Krupnik and Jolly (2002), and Usher's (2001) analysis of shifts in land use in the western Arctic. Cruikshank (2001) analyzes Tlingit stories, recorded by explorers and ethnographers in southeast Alaska in the 19th century, that tell of glacial movements and their impacts on local populations. Her main objective is to explore the link between landscape and culture. The stories picture a northern environment that is not static or immutable, but capable of very rapid change, and a message of uncertainty and unpredictability emerges from the narratives. Although the work is about climate change, it is narrators from another era that are speaking, rather than contemporary populations that perhaps have some informed expectation about climate trends. The result is a highly objective analysis, from which a forceful message about the vagaries of a northern environment emerges almost tangentially. The relevance of the stories to contemporary discussion of climate change is that they underline the fact that confronting changes (often cataclysmic) in northern environments is nothing new, perhaps demonstrating the role of traditional knowledge in equipping the listener to appreciate environments that are subject to change-environments that can surprise.

The use of traditional knowledge to identify contemporary environmental shifts possibly associated with climate change is well exemplified in the papers contained in Krupnik and Jolly's edited work (2002). These papers are grounded in contemporary experience at the community scale, the scale at which change is experienced, in environments where seemingly minor shifts in weather systems have important ramifications for food gathering, access to the land, and overall community well-being. Participatory Action Research, in which host communities facilitate research and play an important role in framing research questions, is used to approach the question of change in some 28 Arctic communities in Canada and Alaska. Together, the works are a compendium of environmental 
stresses, demonstrating the link between climate and land use and the role of TEK in forecasting weather, as well as providing baseline information on the ways in which land use may be affected by climate change. Increasing inability to forecast the weather with the same certainty as in the past (Jolly et al., 2002), ecosystem changes (Thorpe et al., 2002), and recent changes in sea-ice patterns (Krupnik, 2002) strongly indicate that the climate is perhaps changing and demonstrate corroboration between TEK and physical sciences. Overall, the papers constitute a laudably ambitious attempt to reconcile traditional knowledge with conventional science, recognizing both its contemporary relevance and its mutability, reflected in semantic convergence between the language of northern Natives and scientists: "Hunters of today speak increasingly in terms of ecosystems, animal 'behaviour,' contamination, and 'stock health"' (Krupnik, 2002:183). However, there is still some dissonance between what TEK is telling us about trends in northern ecosystems and what science tells us. The paper by Kofinas and the First Nations constituting the Arctic Borderlands Co-op provides numerous examples of events symptomatic of environmental change in the northern Yukon, but points out significant discrepancies between the local population's assessment of trends and the information provided by scientists. These include different estimates of caribou population sizes, the level of contaminants in caribou livers, and the size of the salmon run on the Porcupine River. Differences between the way local land-users encounter wildlife and the way scientists measure it are cited as plausible reasons for the discrepancies (Kofinas et al., 2002).

Taken together, the works in Krupnik and Jolly (2002) paint an eclectic picture of landscapes in transition and land-use practices that are increasingly stressed. Events that are of significance to diverse and highly localized populations are central themes, and these vary from location to location, largely as a reflection of differences in resource use and the ways in which landscapes are interpreted. However, while the contribution that the studies make to the climate change debate is highly significant, Participatory Action Research was the only common methodological element across the widely dispersed communities studied, and an opportunity to conduct a rigorous longitudinal analysis that could have yielded useful information on system-wide trends was perhaps missed.

Usher (2001) uses time-series land-use maps depicting harvesting to identify shifts in the location and nature of harvesting in the Inuvialuit settlement region of the western Arctic. He employs a traditional but rigorous social science approach, using structured surveys to elicit information on the geography of harvest activity, with high response rates. The work is not focused on climate change, and the question of change does not enter into data collection. But (as in Cruikshank, 2001) the question of change enters almost obliquely, and he is thus able to discuss possible climate change implications with considerable objectivity. By contrasting maps made at different times,
Usher is able to identify shifts in the location of harvesting, noting a movement away from marine-based locations and activities towards terrestrial locations. An initial interpretation of such shifts would be that they were primarily due to changes in sea-ice conditions associated with climate change. However, though sea-ice changes appear to be partly responsible, Usher is (rightly) circumspect in seeking explanations for the hunting trend, postulating that uncertainty about weather conditions is only one of a synergistic mix of factors responsible for changes in hunting behaviour. The demise of dog teams is cited as a major factor in shifts in harvesting, and increasing involvement in the wage economy may mean that hunters have less time to spend on the land and thus base their activities closer to home. Changes in local ice conditions do lead harvesters to seek more predictable terrestrial locations, but part of the shift may reflect the relative security that modern communities offer. Improved food security and the intrusion of competing media reduce the incentive (and perhaps the opportunity) to develop a rigorous understanding of regional geography. If traditional geographical knowledge is not being transmitted with the same rigour as it was in the past, then many modern harvesters are as not as well equipped as their ancestors to cope with the vagaries of the marine environment. It follows from this that even if the physical environment were not changing, there would probably be a shift in land-use activity.

\section{DISCUSSION}

It is apparent that making objective assessments of climate change impacts at the community level is fraught with difficulty. Even where changes in behaviour clearly coincide with changes in the physical environment, caution is required in attributing causality. Changes may emanate from societal rather than physical events. Some circumspection is also perhaps in order in assessing the results of community-based research that seeks evidence of climate change. Given that the prognosis of climate change is widely known, do research questions that ask respondents about environmental conditions or evidence of climate change impacts not raise community expectations (or worse, give rise to misplaced apprehension), eliciting positive responses that in reality may be spurious or just plain wrong?

Personal experience takes place in a limited time frame, making it difficult to separate long-term change from aberration. There is also a possible conflict in perspectives. Predictability and preoccupation with the "long term" and "progress" are attributes of modernism that may make it difficult for Southerners to accept the world as an uncertain place. Until relatively recently, the time horizons of northern Natives were considerably different from those of contemporary populations, and adjustment to change and uncertainty was a constant feature of life. Although TEK provides detailed descriptions of local 
geographies and perceived environmental change and plays an important role in corroborating or critically evaluating the prognoses of physical scientists, the quest for evidence of contemporary climate change is perhaps not primarily a social science question.

What we need to know, and what lies fairly in the purview of social scientists, is how human activity will respond to change. From the standpoint of affected populations, the important questions are "What will the impact be on way of life?" and "How shall we adapt?" Unfortunately, unlike their counterparts in the physical sciences, research efforts in the social sciences are somewhat dilute. They are neither systematic nor systemic, and they fall short of either providing local populations with a sense of what to expect, or providing decision makers with assessments of probable impacts as a basis for prioritizing responses and allocating resources. To this point, little more has been accomplished than demonstrating that environments in the North are perceived to be changing. It is difficult to establish the ultimate significance of described stresses because there is a paucity of well-organized data on initial conditions in communities, such as locational context, demography, community history, or economic complexity, that would give insights into the way in which change may be received and transmitted. The need to understand more about community conditions has emerged at a time when social scientists have been obliged to reassess the manner in which they conduct research in the North, in the face of concerns about the intrusive nature of research methodologies, poor communication with affected populations, and conflicts over the ownership of research results. Sensitivity to these concerns is reflected in the search for new social science paradigms in community change research, but given the apparent rapidity at which northern environments are perceived to be changing, do we really have the luxury of using the climate change question as a vehicle for experimenting with new techniques? At the current pace of research, change may outstrip the ability to make reasoned assessments of its nature or its impacts.

Systematic investigation of current conditions in communities across the North is needed with some expediency, both as a basis for comparative assessment of vulnerability to climate change and to inform decisions about the allocation of resources in support of mitigative measures. This would entail community-by-community analysis of current conditions and a review of those dynamic components of community life that would condition attitudes towards change. Timeliness, clear and rigorous methodologies that allow for longitudinal analysis of data, minimal community intrusion, and findings that are easily communicated to affected populations so that they can respond to them should be features of such an endeavour. Over the past 60 years, there has been a sustained tradition of northern settlement studies, reflecting both prevailing academic wisdom and pragmatic concerns. Economic base, quality of life, and sustainable development have variously been the focus of studies, with vulnerability and resilience as recurring themes, and this tradition assumes renewed importance in assessing community impacts of climate change. A detailed systematic scan of the physical context, natural hazard history, demography, economy, and transactional structure of each northern community would serve as a basis for identifying predisposition to impact under different climate change scenarios. Given the volume of research over the past 20 years, a useful and systematic picture of community vulnerability to climate change could be built with relatively little intrusion. There are extensive secondary resources that can already yield much (if not all) of the data required on the current disposition of communities. Some sources are obvious: remote-sensed imagery; various socio-economic assessments related to mega-project proposals; extensive data generated on land use and occupancy as a basis for land-claim negotiations (which have covered all of Arctic Canada over the past 20 years); and data generated in support of the Northern Contaminants Program, which could provide important information about current dependency on the land. Additionally, a large number of research reports exist on various aspects of life in northern communities, and considerable demographic information lies in the public record. Information on community experience of and vulnerability to hazards rests in government departments, and in some areas, a considerable record can be found in the pages of long-established community newspapers. This approach would minimize community intrusion and be relatively cost-effective, because no extensive fieldwork or generation of primary community data would be required.

\section{CONCLUSIONS}

Although physical environments at high latitudes will be more greatly affected by climate change than those found elsewhere in North America, it is not appropriate to extrapolate this effect uncritically into prognoses of necessarily dire human impacts. Populations are not passive players. Their responses will be conditioned by the long history of uncertain environments and the local context in which they live. Systematic research focusing on human activity at the local scale is important in moving toward an objective assessment of probable impacts of climate change, reducing uncertainty and providing decision makers with structured information that can delimit likely scenarios and form a rational basis for allocating resources.

In the course of this paper, it has been suggested that two lines of research lead towards an informed sense of probable human impacts: the analysis of what is already known about the character of northern communities and the use of the current perspectives and observations of resident populations. Social science research has an important role in the climate change debate, underscoring the strong link between the well-being of northern communities 
and their immediate environments, demonstrating the role of TEK and narrative in addressing uncertainty, and revealing the complexity of community economies that makes translation of climate change into community-level impacts a difficult task. Practically, at the community level, it can assist communities that are already experiencing change to translate those changes into probable longerterm impacts on their way of life.

\section{REFERENCES}

ADGER, W.N., and KELLY, P.M. 1999. Social vulnerability to climate change and the architecture of entitlements. Mitigation and Adaptation Strategies for Global Change 4:253-266.

AHARONIAN, D. 1994. Land use and climate change: An assessment of climate-society interactions in Aklavik, NT. In: Cohen, S.J., ed. Mackenzie Basin Impact Study. Interim Report \#2. Downsview, Ontario: Environment Canada. 410-420.

BERKES, F. 1999. Indigenous knowledge systems and resource management systems in the Canadian Subarctic. In: Berkes, F., and Folke, C., eds. Linking social and ecological systems. Cambridge: Cambridge University Press. 98-128.

- 2002. Epilogue: Making sense of Arctic environmental change? In: Krupnik, I., and Jolly, D., eds. The earth is faster now: Indigenous observations of Arctic environmental change. Fairbanks, Alaska: Arctic Research Consortium of the United States. 335-349.

COHEN, S.J., ed. 1997. Mackenzie Basin Impact Study: Final Report. Environment Canada and the University of British Columbia. Ottawa: Minister of Supply and Services.

COMISO, J.C. 2003: Warming trends in the Arctic from clear sky satellite observations. Journal of Climate 16(21):3498-3510.

CRUIKSHANK, J. 2001. Glaciers and climate change: Perspectives from oral tradition. Arctic 54(4):377-393.

CUTTER, S.L. 1996. Vulnerability to environmental hazards. Progress in Human Geography 20(4):529-539.

DUERDEN, F. 2001. Climate change and human activity in northern Canada: What we know, don't know, and need to know. Northern Review 24:150-160.

DUERDEN, F., and KUHN, R.G. 1998. Scale, context, and application of traditional knowledge of the Canadian North. Polar Record 34(188):31-38.

FAST, H., and BERKES, F. 1998. Climate change, northern subsistence and land-based economies. In: Wall, J., Freeman, M.M.R., McCormack, P.A., Payne, M., and Wein, R.W., eds. Securing northern futures. Edmonton: Canadian Circumpolar Institute. 9-19.

FOX, S. 2000. Arctic climate change: Observations from the Inuvialuit settlement region. In: Fetterer, F., and Radionov, V., eds. Arctic Climatology Project-Environmental Working Group Arctic Meteorology and Climate Atlas. Boulder, Colorado: National Snow and Ice Data Center. CD-ROM.

- 2002. These are things that are really happening: Inuit perspectives on the evidence and impacts of climate change in Nunavut. In: Krupnik, I., and Jolly, D., eds. The earth is faster now: Indigenous observations of Arctic environmental change.
Fairbanks, Alaska: Arctic Research Consortium of the United States. 12-53.

GOVERNMENT OF THE NORTHWEST TERRITORIES. 2003. Components of population change by time period Northwest Territories-April 1, 1993 to July 1, 2003. Yellowknife: NWT Bureau of Statistics.

GOVERNMENT OF YUKON, 2002. Yukon migration patterns 1991-2001. Publication (A-8C). Whitehorse: Bureau of Statistics.

HANDMER, J.W., DOVERS, S., and DOWNING, T.E. 1999. Societal vulnerability to climate change and variability. Mitigation and Adaptation Strategies for Global Change 4: $267-281$.

HUANG, G.H., COHEN, S.J., YIN, Y.Y., and BASS, B. 1998. Land resources adaptation planning under a changing climate, a study for the Mackenzie Basin. Resources, Conservation and Recycling 24(2):95-119.

HUGHEN, K., and THE PALE HIGH-RESOLUTION RESEARCH GROUP. 1998. Past environmental changes in the Arctic: A PALE contribution to Arctic system science. Witness the Arctic 6(1): $1-3$.

HUNTINGTON, H.P. 2000. Native observations capture impacts of sea ice changes. Witness the Arctic 8(1):1-2.

IASC (INTERNATIONAL ARCTIC SCIENCE COMMITTEE). 1999. Impacts of global climate change in Arctic regions. Fairbanks: Center for Global Change Research, University of Alaska.

. 2001. Climate change 2001: The scientific basis. Edited by J.T. Houghton, Y. Ding, D.J. Griggs, M. Noguer, P.J. van der Linden, X. Dai, K. Maskell, and C.A. Johnson. Cambridge: Cambridge University Press.

JOLLY, D., BERKES, F., CASTLEDEN, J., NICHOLS, T., and THE COMMUNITY OF SACHS HARBOUR. 2002. We can't predict the weather like we used to: Inuvialuit observations of climate change, Sachs Harbour, Western Canadian Arctic. In: Krupnik, I., and Jolly, D., eds. The earth is faster now: Indigenous observations of Arctic environmental change. Fairbanks, Alaska: Arctic Research Consortium of the United States. 92-125.

KELLY, P.M., and ADGER, W.N. 2000. Theory and practice in assessing vulnerability to climate change and facilitating adaptation. Climatic Change 47(4):325-352.

KENDRICK, A. 2000. Community perceptions of the BeverlyQamanirjuaq Caribou Management Board. Canadian Journal of Native Studies 20(1):1-33.

KOFINAS, G., with THE COMMUNITIES OF AKLAVIK, ARCTIC VILLAGE, OLD CROW, and FORT McPHERSON. 2002. Community contributions to ecological monitoring: Knowledge co-production in the U.S.-Canada Arctic Borderlands. In: Krupnik, I., and Jolly, D., eds. The earth is faster now: Indigenous observations of Arctic environmental change. Fairbanks, Alaska: Arctic Research Consortium of the United States. 54-91.

KRUPNIK, I. 2002. Watching ice and weather our way: Some lessons from Yupik observations of sea ice and weather on St. Lawrence Island, Alaska. In: Krupnik, I., and Jolly, D., eds. The earth is faster now: Indigenous observations of Arctic 
environmental change. Fairbanks, Alaska: Arctic Research Consortium of the United States. 156-197.

KRUPNIK, I., and JOLLY, D. 2002. The earth is faster now: Indigenous observations of Arctic environmental change. Fairbanks, Alaska: Arctic Research Consortium of the United States.

LEWIS, J.E., and WOOD, E. 1995. A physical scientist's perspective on the human dimensions of global change. Topics in Arctic Social Science 2:1-18.

LONEGRAN, S.C., DiFRANCESCO, R., and WOO, M. 1993. Climate change and transportation in northern Canada: An integrated impact assessment. Climatic Change 24:331-351.

MAXWELL, B., ed. 1997. Canada country study: Climate impacts and adaptation. Vol. 2: Responding to global climate change in Canada's Arctic. Toronto: Environment Canada.

McDONALD, M., ARRAGUTAINAQ, L., and NOVALINGA, Z. 1997. Voices from the Bay: Traditional ecological knowledge of Inuit and Cree in the Hudson Bay bioregion. Ottawa: Canadian Arctic Resources Committee and the Environmental Committee of Municipality of Sanikiluaq.

McGIllivarY, D.G., AGNEW, T.A., McKAY, C.A., PILKINGTON, G.R., and HILL, M.C. 1993. Impacts of climate change on the Beaufort Sea ice regime: Implications for the Arctic petroleum industry. Climate Change Digest 93-01. Downsview, Ontario: Atmospheric Environment Service. 17 p.

MILLS, P.1994. The agricultural potential of northwestern Canada and Alaska and the impact of climatic change. Arctic 47(2): $115-123$.

NORTHERN CLIMATE EXCHANGE. 2000. A northern assessment of impacts of climate change: Defining our knowledge base and research priorities. Proceedings of a conference held in Whitehorse, September, 2000. Whitehorse, Yukon: Northern Climate ExChange.

- 2001. Gap analysis project. Whitehorse, Yukon: Northern Climate ExChange.

NOONGWOOK, G. 2000. Native observations of local climate changes around St. Lawrence Island. In: Huntington, H.P., ed. Impacts of changes in sea ice and other environmental parameters in the Arctic. Bethesda, Maryland: Marine Mammal Commission. 21-24.

NUTTALL, M. 2001. Indigenous peoples and climate change research in the Arctic. Indigenous Affairs 4\2001:26-34.

QUIGLEY, N.C., and McBRIDE, N.J. 1987. The structure of an Arctic microeconomy: The traditional sector in community economic development. Arctic 40(3):204-210.
REIDLINGER, D., and BERKES, F. 2001. Contributions of traditional knowledge to understanding climate change in the Canadian Arctic. Polar Record 37(20):315-329.

ROTHMAN, D., and HERBERT, D. 1997. The socio-economic implications of climate change in the forest sector of the Mackenzie Basin. In: Cohen, S., ed. Mackenzie Basin Impact Study, Final Report. Ottawa: Minister of Supply and Services. 233-241.

SMIT, B., and PILIFOSOVA, O. 2002. From adaptation to adaptive capacity and vulnerability reduction. In: Huq, S., Smith, J., and Klein, R.T.J., eds. Enhancing the capacity of developing countries to adapt to climate change. London: Imperial College Press. $1-20$.

SNOW, N., and CARPENTER, L. 2001. Inuit observations on climate change: Local action and global impact. Paper presented at Climate Change in the Circumpolar North Summit, March 19, 2001, Whitehorse, Yukon.

TAYLOR, E., and TAYLOR, B., eds. 1997. Canada country study: Climate impacts and adaptation. Vol. 6: Responding to global climate change in British Columbia and Yukon. Vancouver: Environment Canada.

THORPE, N., EYEGETOK, S., HAKONGAK, N., and the KITIKMEOT ELDERS. 2002. Nowadays it is not the same: Inuit qaujimajatuqangit, climate and caribou in the Kitikmeot Region of Nunavut, Canada. In: Krupnik, I., and Jolly, D., eds. The earth is faster now: Indigenous observations of Arctic environmental change. Fairbanks, Alaska: Arctic Research Consortium of the United States. 198-239.

USHER, P.J. 2002. Inuvialuit use of the Beaufort Sea and its resources. Arctic 55(Supp. 1):18-28.

WATSON, R.T., ZINYOWERA, M.C., MOSS, R.H., and DOKKEN, D.J., eds. 1997. IPCC Special Report on the regional impacts of climate change: An assessment of vulnerability. Summary for policymakers. Geneva, Switzerland: Intergovernmental Panel On Climate Change.

WEIN, E.E., and WEIN, R.W. 1995. Predictions of global warming influences on aboriginal food use patterns in northwestern Canada. The Northern Review 14:86-94.

WILLIAMSON, T. 1997. From Sina to Sikujaluk: Our footprint. Mapping Inuit environmental knowledge in the Nain district of northern Labrador. Available from the Labrador Inuit Association, 12 Sandbanks Rd., Nain, Labrador A0P 1L0, Canada. 